\title{
Why do mesophotic coral ecosystems have to be protected?
}

\author{
Marcelo de Oliveira Soares ${ }^{\mathrm{a}, \mathrm{b}, \mathrm{c}, *}$, Jorge Thé de Araújo $^{\mathrm{a}}$, Sarah Maria Cavalcante Ferreira ${ }^{\mathrm{a}}$, \\ Braúlio Almeida Santos ${ }^{\mathrm{d}}$, Joana Ruela Heimbürger Boavida ${ }^{\mathrm{e}, \mathrm{f}}$, Federica Costantini ${ }^{\mathrm{g}, \mathrm{h}}$, Sergio Rossi ${ }^{\mathrm{b}, \mathrm{c}, \mathrm{h}}$ \\ a Instituto de Ciências do Mar-LABOMAR, Universidade Federal do Ceará, Av. da Abolição, 3207, Fortaleza, Brazil \\ ${ }^{\mathrm{b}}$ Institut de Ciència i Tecnologia Ambientals (ICTA), Universitat Autònoma de Barcelona (UAB), Carrer de les Columnes, Edifici Z, Cerdanyolla del Vallés, Barcelona, Spain \\ ${ }^{\mathrm{c}}$ Dipartimento di Scienze e Tecnologie Biologiche e Ambientali (DISTEBA), Università del Salento, Lecce, Italy \\ d Universidade Federal da Paraíba, Centro de Ciências Exatas e da Natureza, Departamento de Sistemática e Ecologia, João Pessoa, Brazil \\ e Mediterranean Institute of Oceanography-MIO, Campus de Luminy, 163 Avenue de Luminy, Marseille, France \\ f Centro de Ciências do Mar (CCMAR), Universidade do Algarve, Campus de Gambelas, Faro, Portugal \\ g Dipartimento di Scienze Biologiche, Geologiche ed Ambientali (BiGeA) and Centro Interdipartimentale di Ricerca per le Scienze Ambientali (CIRSA), University of Bologna, Ravenna, Italy \\ ${ }^{\mathrm{h}}$ Consorzio Nazionale Interuniversitario per le Scienze del Mare (CoNISMa), Rome, Italy
}

\section{ART ICLE INFO}

\section{Article history:}

Received 12 July 2019

Received in revised form 4 March 2020

Accepted 3 April 2020

Available online xxx

Editor: Julian Blasco

\section{Keywords}

Coral reef

Twilight zone

Climate change

Marine protected area

Human effect

Global warming

\begin{abstract}
A B S T R A C T
Mesophotic coral ecosystems (MCEs; $\sim 30-150 \mathrm{~m}$ depth) are among the most biologically diverse and least protected ecosystems in the world's oceans. However, discussions regarding the conservation of these unique ecosystems are scarce. To address this issue, we identified the features of MCEs that demonstrate they should be considered as a global conservation priority. Some MCEs are characterized by their well-preserved and unique seascapes; their narrow environmental tolerance and high vulnerability to anthropogenic effects; and their slow recovery and reduced reproductive performance. The unique biodiversity of MCEs includes depth-adapted specialist species and new species, most of which are threatened or important fishery resources. MCEs also provide refuge against human stressors, valuable ecosystem services, and ecological connectivity. MCEs generally meet the criteria to be classified as Ecologically and Biologically Significant Marine Areas under the Convention on Biological Diversity. However, we highlight that many MCEs worldwide are threatened and not yet adequately protected by fishery regulations, marine protected areas, or considered in marine spatial planning. Establishing MCEs as a global conservation priority requires the designation of national, international, transnational, public, and private policies.
\end{abstract}

(C) 2018

\section{Introduction}

Centuries of oceanographic expeditions and museum collections have indicated the existence of three-dimensional ecosystems in deep waters worldwide (Baker et al., 2016). However, detailed descriptions of the ocean's twilight zone ( $\sim 30-150 \mathrm{~m}$ depth) have only emerged in the last few decades, with the use of modern oceanographic technologies (Kahng et al., 2017). Corals and light-dependent organisms inhabit many deep habitats, particularly in tropical and subtropical ecoregions (sensu Spalding et al., 2007), which are classified as mesophotic coral ecosystems (MCEs) (Lesser et al., 2009; Hinderstein et al., 2010; Turner et al., 2017). In temperate regions, TMEs (temperate mesophotic ecosystems) are also defined as light-dependent communities located at $\sim 30-150 \mathrm{~m}$ depth (Turner et al., 2019).

\footnotetext{
* Corresponding author at: Instituto de Ciências do Mar-LABOMAR, Universidade Federal do Ceará, Av. da Abolição, 3207, Fortaleza, Brazil.

E-mail address: marcelosoares@ufc.br (M.d.O. Soares)
}

Scientific interest in MCEs was initially driven by the ability of MCEs to buffer shallow tropical corals (Lesser et al., 2009; Rocha et al., 2018; Bongaerts and Smith, 2019). However, MCEs are increasingly receiving attention from the scientific community and the general public for their unique biodiversity and ecological importance. Yet, despite decades of research, many questions remain unanswered (Turner et al., 2019). MCEs may have the limited potential to reseed overexploited and stressed species in shallower waters (Loya et al., 2016; Kahng et al., 2017). However, MCEs (particularly the deepest at 70-150 m) are distinct from shallow-water tropical coral reefs, which have limited potential to act as refuges and are subject to multiple anthropogenic pressures (Rocha et al., 2018; Soares et al., 2019; Soares 2020).

Mesophotic zone ecosystem composition varies according to the geographic area and has a heterogeneous nature in their structure and functioning (e.g., MCEs in seamounts, volcanic islands and continental slopes). In the coralligenous (Mediterranean Sea) and temperate Northeastern Atlantic Ocean, heterotrophic suspension feeding organisms dominate temperate mesophotic ecosystems (Costantini et al., 2011 ; 
Boavida et al., 2016a, 2016b), whereas in tropical MCEs, rhodoliths, sponges, black corals, gorgonians, and massive corals dominate (Pyle and Copus, 2019; Soares et al., 2019). Similar to shallow-water coral reefs, MCEs provide ecosystem goods and services (EGS) (Baker et al., 2016). Currently, it is well established that MCEs are important for reef biodiversity maintenance and provide fisheries resources (Kahng et al., 2017). In this way, MCEs represent an important component of coral reef ecosystems - potentially up to $80 \%$ of reef habitat worldwide (based on depth) (Pyle and Copus, 2019). However, research has only been conducted over one decade; therefore, whether MCEs provide other EGS, for example, whether they act as potential source populations for shallow reefs or as carbon sinks, remains to be clarified (Costantini et al., 2011; Rossi et al., 2017).

Despite their recognized importance, most MCEs do not receive protection from marine protected areas (MPAs) and are underrepresented in marine spatial planning (MSP) directives (Rocha et al., 2018; Soares et al., 2019). Human activity is expected to increase anthropogenic pressure on the twilight ocean zones over the following decades (Frade et al., 2018; Soares et al., 2019). Therefore, policies governing the conservation of marine ecosystems that incorporate the unique and threatened biodiversity of MCEs must be developed (Bridge et al., 2013; Turner et al., 2019).

Recent reviews (Hinderstein et al., 2010; Bridge et al., 2013; Loya et al., 2016; Kahng et al., 2014, 2017; and Turner et al., 2019) have suggested that MCEs are among the richest (i.e., in terms of endemic and rare species) and least protected ecosystems in world's oceans. However, despite their importance within the context of global environmental change, discussions regarding the conservation of MCEs and their required management actions are scarce (Kahng et al., 2017; Smith et al., 2019; Turner et al., 2017, 2019).

Accordingly, MCEs urgently need to be considered as a global priority for ocean conservation, which will require the development of national, international, transnational, public, and private policies. In this review, we identify the features of MCEs that support their prioritization in ocean conservation policies. We also discuss the urgent actions that must be taken on a global level if we are to protect MCEs from ongoing and future effects. Such actions include the establishment of MPAs, ocean zoning, and MSP. Our article is an opinionated analysis, designed to stimulate debate and action toward MCE conservation policies.

\section{MCEs as a global priority for ocean conservation: Key features}

MCEs are characterized by a set of key features (Table 1). Furthermore, MCEs meet the international criteria used to identify priority areas for conservation policies (Table 1). Asaad et al. (2017) reviewed the criteria used by 15 international initiatives and found eight common criteria used to identify areas for biodiversity conservation. More recently, Johnson et al. (2018) reviewed the seven key scientific criteria for the implementation of Ecologically or Biologically Significant Areas (EBSAs), according to the Convention on Biological Diversity (CBD). These criteria, along with the key features of MCEs, are summarized below.

\subsection{Under pressure: threats and fragilities of MCEs}

Some of the most remarkable examples of MCEs are found in Australia (Sih et al., 2017), Africa (Morais and Maia, 2017), the Gulf of Mexico (Muñoz et al., 2017), eastern Brazil (Pinheiro et al., 2017), Hawaii (Pyle et al., 2016), the Caribbean Sea (Trembanis et al., 2017), the Coral Triangle in the Indo-Pacific, the Red Sea (Shoham and Benayahu, 2017), and the Amazon continental shelf (Francini-Filho et al., 2018; Fig. 1). In many marine ecoregions, the pristine or well-preserved nature of MCEs (Loya et al., 2016; Kahng et al., 2017) distinguishes them from the nearby tropical shallow reefs, which
Table 1

Key features of mesophotic coral ecosystems (MCEs) and international criteria used to identify areas for biodiversity conservation (Asaad et al., 2017) and classify Ecologically or Biologically Significant Areas (EBSAs; Johnson et al., 2018) under the Convention on Biological Diversity (CBD).

\begin{tabular}{|c|c|c|c|}
\hline Key features of MCEs & $\begin{array}{l}\text { Criteria to } \\
\text { identify areas } \\
\text { for } \\
\text { biodiversity } \\
\text { conservation }^{\text {a }}\end{array}$ & $\begin{array}{l}\text { CBD-approved } \\
\text { scientific } \\
\text { criteria for the } \\
\text { assessment } \\
\text { and } \\
\text { description of } \\
\text { EBSAs }\end{array}$ & References \\
\hline $\begin{array}{l}\text { MCEs contain unique } \\
\text { habitats; MCEs are } \\
\text { distinct because they have } \\
\text { unique geomorphological, } \\
\text { ecological, and } \\
\text { oceanographic features. } \\
\text { These features differ } \\
\text { between the shallow reefs } \\
\text { and the MCEs. }\end{array}$ & $\begin{array}{l}\text { Contain } \\
\text { unique and } \\
\text { rare habitats }\end{array}$ & $\begin{array}{l}\text { Uniqueness or } \\
\text { rarity }\end{array}$ & $\begin{array}{l}\text { Rocha et al. } \\
(2018) \text {, } \\
\text { Soares et al. } \\
(2019) \text { and } \\
\text { Hinderstein } \\
\text { et al. (2010) }\end{array}$ \\
\hline $\begin{array}{l}\text { MCEs contain high } \\
\text { proportions of sensitive } \\
\text { habitats and species. } \\
\text { MCEs are susceptible to } \\
\text { local (i.e., pollution, } \\
\text { overfishing) and global } \\
\text { effects (i.e., warming, } \\
\text { acidification) and natural } \\
\text { events (i.e., storms, } \\
\text { hurricanes); common reef- } \\
\text { building species exhibit }\end{array}$ & $\begin{array}{l}\text { Include fragile } \\
\text { and sensitive } \\
\text { habitats }\end{array}$ & $\begin{array}{l}\text { Vulnerability, } \\
\text { fragility, } \\
\text { sensitivity, or } \\
\text { slow recovery }\end{array}$ & $\begin{array}{l}\text { Frade et al. } \\
\text { (2018), } \\
\text { Groves et al. } \\
\text { (2018), Muir } \\
\text { et al. (2017), } \\
\text { Rocha et al. } \\
\text { (2018), } \\
\text { Shlesinger et } \\
\text { al. (2018) and } \\
\text { Soares et al. } \\
\text { (2019) }\end{array}$ \\
\hline $\begin{array}{l}\text { slow recoveries (i.e., } \\
\text { scleractinian corals and } \\
\text { black corals), reduced } \\
\text { coral reproductive } \\
\text { performance and } \\
\text { narrower tolerance to } \\
\text { environmental factors. }\end{array}$ & & & \\
\hline $\begin{array}{l}\text { Compared to the soft- } \\
\text { bottom mesophotic } \\
\text { habitats, MCEs exhibit } \\
\text { higher productivity (i.e., } \\
\text { secondary production); } \\
\text { MCEs are also important } \\
\text { for ecological integrity } \\
\text { and are potential refuges } \\
\text { against local and global } \\
\text { human stressors for some } \\
\text { species. }\end{array}$ & $\begin{array}{l}\text { Are important } \\
\text { for ecological } \\
\text { integrity }\end{array}$ & $\begin{array}{l}\text { Biological } \\
\text { productivity }\end{array}$ & $\begin{array}{l}\text { Bridge et al. } \\
\text { (2013), Frade } \\
\text { et al. (2018), } \\
\text { Kahng et al. } \\
(2014,2017)\end{array}$ \\
\hline $\begin{array}{l}\text { Because of their distance } \\
\text { from the coast and } \\
\text { location in deeper waters, } \\
\text { MCEs in some places have } \\
\text { a higher degree of } \\
\text { naturalness (i.e., well- } \\
\text { preserved ecosystems) } \\
\text { than surrounding } \\
\text { shallower ecosystems. } \\
\text { They are spread } \\
\text { throughout the world } \\
\text { ocean, occurring in most } \\
\text { global marine ecoregions. }\end{array}$ & & Naturalness & $\begin{array}{l}\text { Baker et al. } \\
\text { (2016), } \\
\text { Boavida et al. } \\
\text { (2016), } \\
\text { Bongaerts et } \\
\text { al. (2010), } \\
\text { Turner et al. } \\
(2017) \text {, } \\
\text { Soares et al. } \\
\text { (2019) }\end{array}$ \\
\hline
\end{tabular}




Key features of MCEs
MCEs provide habitats for
the survival and recovery
of some endangered,
threatened, and declining
reef species (i.e., fishery
resources and threatened
corals).

MCEs have restrictedrange reef species (30-150 m depth) because of their location between shallow and deep waters and presence of lightdependent corals and algae. MCEs are distinct from shallow-water coral reefs.

Compared to the surrounding soft-bottom mesophotic habitats, MCEs contain higher species diversity because of the higher habitat complexity (i.e., reefs, sponge bottoms and black coral forests) and the presence of endemic species adapted to the twilight zone. MCEs function as nurseries (i.e., fishes, corals, sponges, and algae).
CBD-approved

scientific

Criteria to

identify areas

for

biodiversity description of

conservation $^{\text {a }}$ EBSAs ${ }^{\text {b }}$

Include species of conservation concern

\section{Importance for} threatened, endangered, or declining species and/or habitats

$\begin{array}{ll}\text { Include } & \text { Kosaki et al. } \\ \text { restricted- } & \text { (2017), Rocha } \\ \text { range species } & \text { et al. (2018), } \\ & \text { Semmler et } \\ & \text { al. (2017) }\end{array}$

$\begin{array}{lll}\begin{array}{l}\text { Present species } \\ \text { richness and }\end{array} & \begin{array}{l}\text { Biological } \\ \text { diversity and }\end{array} & \begin{array}{l}\text { Kosaki et al. } \\ \text { (2017), }\end{array} \\ \text { importance for } & \text { importance for } & \text { Muñoz et al. } \\ \text { life history } & \text { life history } & \text { (2017), } \\ \text { stages } & \text { stages of } & \text { Soares et al. } \\ & \text { species } & (2019)\end{array}$

a Asaad et al. (2017).

b Reviewed in Johnson et al. (2018). have often undergone profound transformations over the preceding decades (Mumby, 2009; Hughes et al., 2018).

As MCEs primarily occur in deep waters $(\sim 30-150 \mathrm{~m}$ depth) in areas located away from many human activities (i.e., outside of the direct influence of domestic, agricultural, and industrial effluents), they are characterized by well-preserved seascapes and species. For example, because their upper (depth) limit corresponds to the maximum depth of SCUBA diving (approximately 25-30 m depth), MCEs are not used as recreational diving areas and are only reachable with specialized equipment and training (Rossi et al., 2008). However, recent research has shown that in marine ecoregions (sensu Spalding et al., 2007) such as Tropical Southwestern Pacific, Tropical Northwestern Atlantic (Rocha et al., 2018), North Brazil Shelf and the Tropical Southwestern Atlantic (Soares et al., 2019), natural disturbances (e.g., storms and hurricanes) and human effects (e.g., fishing and plastic debris) have affected MCEs and may threaten their unique biodiversity. Moreover, most of the Coral Triangle MCEs are found on the outer barrier slopes and are close from urban centers, which means that in some areas the MCEs are close to many human activities and their impacts (Longenecker et al., 2019). Furthermore, MCEs are susceptible to a wide range of other threats, including inorganic and organic contaminants (Bigus et al., 2014; Cai et al., 2016), ocean acidification (Baker et al., 2016), increased prevalence of disease outbreaks (Smith et al., 2019), invasive species (Andradi-Brown, 2019; Soares et al., 2019), environmental disasters (Silva et al., 2016; Soares et al., 2020), and thermal stress as a result of a low bleaching threshold (Frade et al., 2018).

Compared to shallow-water reefs, MCEs contain a higher proportion of vulnerable habitats and foundation species (Jones et al. 1994) that are fragile and slow-growing (Kahng et al., 2017; Sih et al., 2017). Such low growth rates are a result of reduced irradiance, which makes their symbiont clade and density different from that of surface corals (Iglesias-Prieto et al., 2004). In fact, some cnidarian species may or may not hold symbionts depending on depth. This causes differences in energy storage capacity, with energy storage higher in the shallow symbiont-bearing coral patches than in the deeper-nonbearing patches (Gori et al., 2012).

In assessing the susceptibility of MCEs to temperature anomalies, it is important to not only consider their low bleaching thresholds but also their exposure to elevated temperatures. A recent study that assessed the incidence of bleaching in corals along a depth gradient showed that bleaching decreases sharply with depth (Muir et al.,

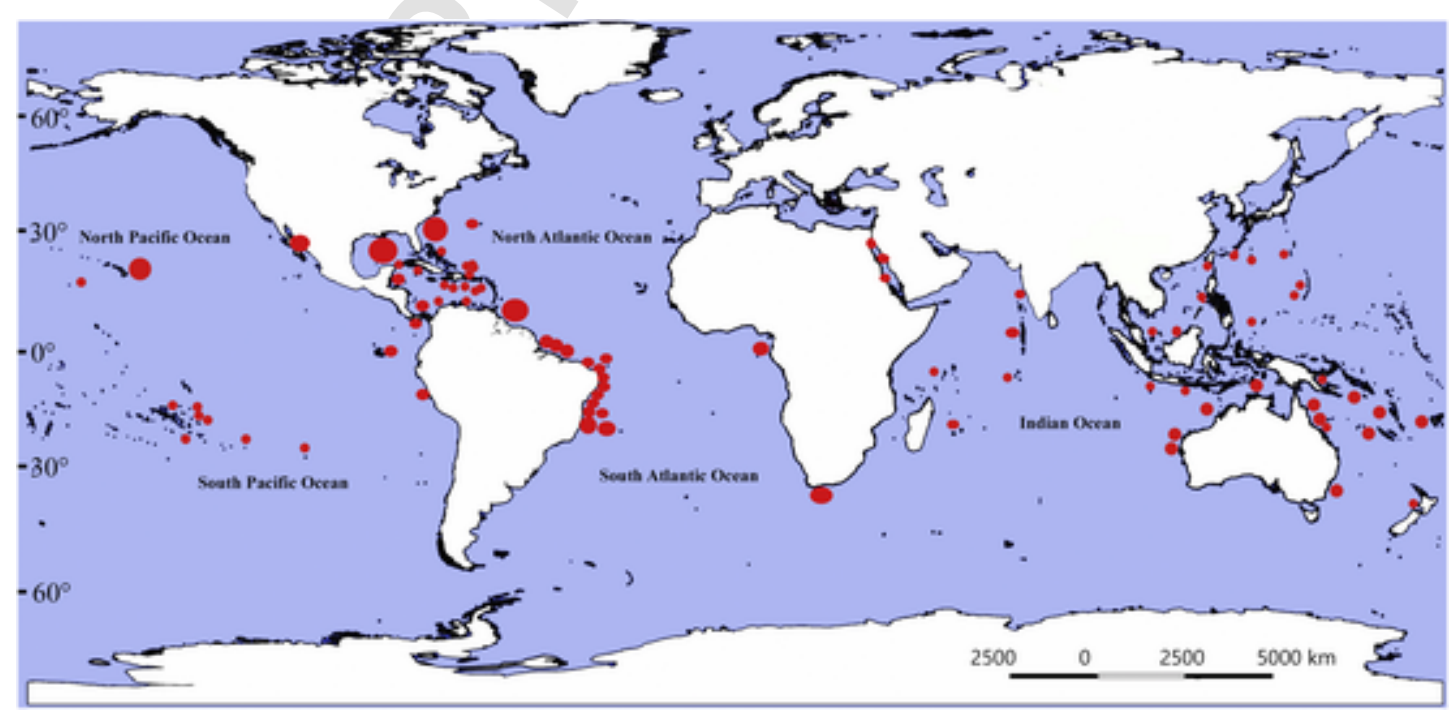

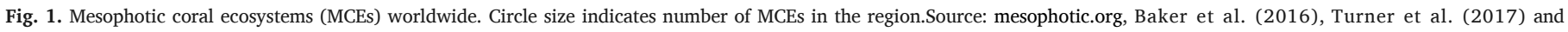
Soares et al. (2019). 
2017), suggesting that MCEs may have some resilience against thermal anomalies. However, Frade et al. (2018) found that while summer upwelling initially provided thermal relief at upper mesophotic depths $(40 \mathrm{~m})$ in the Great Barrier Reef, this later subsided, resulting in anomalously warm temperatures even at increased depths. Although subsequent bleaching effects on the mesophotic reefs were severe $(40 \%$ bleached and $6 \%$ dead colonies at $40 \mathrm{~m}$ ), they were significantly lower than that observed at shallower depths (60-69\% bleached and $8-12 \%$ dead at 5-25 m; Frade et al., 2018).

Projected warming rates and the existing "community thermal safety margin" (the inherent buffer against temperature anomalies based on thermal sensitivity of constituent species; Bruno et al., 2018) may vary with the latitude among ecoregions and MCEs. However, what constitutes the safe thermal range for MCEs is not well understood, and it may be lower than that for shallow-water communities, especially in tropical coasts with a unithermal water column (the same temperature from the surface to the sea floor at mesophotic depths) (Venegas et al., 2019). A recent study showed that thermal stress events can penetrate to the depths where MCEs are found (Frade et al., 2018; Venegas et al. 2019), meaning the twilight zone may not represent a thermal refuge for corals. Therefore, it is possible that the tolerance of MCEs to certain environmental changes, such as shifts in temperature and $\mathrm{pH}$, is narrower than that of shallow-water coral ecosystems (Shlesinger et al., 2018).

There is increasing concern regarding the vulnerability of MCEs worldwide (Rocha et al., 2018; Soares et al., 2019). Yet, the lack of long-term monitoring has prevented direct observation of anthropogenic ocean acidification owing to increasing atmospheric $\mathrm{CO}_{2}$ in these mesophotic ecosystems. The effect of acidification on MCEs is likely to be different to that for shallow-water reefs, as well as region-dependent. This is because net ecosystem production (NEP = gross primary production - autotrophic and heterotrophic respiration) and net ecosystem calcification $\left(\mathrm{NEC}=\right.$ gross calcification - gross $\mathrm{CaCO}_{3}$ dissolution) are generally lower in shallow-water reefs. Bramanti et al. (2013) assessed the effects of ocean acidification on a mesophotic species (red coral at $14{ }^{\circ} \mathrm{C}$ ) and observed a net loss of calcification and a significant change in energy storage capability with respect to the normal conditions. However, the effect of ocean acidification on MCEs remains unclear (Morais et al., 2018).

\subsection{Limited potential refuge against human effects}

The concept of MCEs as a reproductive refuge became known as the "deep reef refugia hypothesis" (DRRH) (Bongaerts et al., 2010). The DRRH suggests that the incidence and intensity of coral bleaching; the presence of diseases in key reef-building species; and the occurrence of storms and hurricanes, are lower in MCEs than in shallow-water coral reefs (Loya et al., 2016; Abesamis et al., 2017; Kahng et al., 2017). In addition, the offshore location of MCEs may mean that they are subject to less anthropogenic pressure from chronic pollution from coastal cities, physical effects (e.g., marine debris, anchoring, benthic infrastructure), overfishing, and high loads of sediments and turbidity (Abaya et al., 2018; Smith et al., 2019). However, in shallower continental shelves and lagoon atoll MCEs can occur close to the human populations, where they are affected by coastal runoff (e.g., plastics, microplastics and extreme floods; Soares et al., 2019; Zhang et al., 2019), abandoned fishing gears (Ballesteros et al., 2018), chemical contaminants (e.g., polycyclic aromatic hydrocarbons, organochlorine pesticides, and polychlorinated biphenyls [PCBs]; Cai et al., 2016; Jafarabadi et al., 2017, 2019a), labile dissolved organic carbon (Bednarz et al., 2020), metals (Ricolleau et al., 2019; Schyff et al., 2020), and fishing activities (Rocha et al., 2018; Soares et al., 2019). Furthermore, persistent organic pollutants such as PCBs can have detrimental effects on ecological systems such as MCEs owing to their high toxicity, lipophilic properties, and widespread dispersal in the marine environment (Jafarabadi et al., 2019a, 2019b). These threats and others (e.g., heatwaves, warming and acidification) discussed in this manuscript may undermine the ability of MCEs to act as a depth refugium or depth resilience areas (sensu Bongaerts and Smith, 2019).

There is little empirical evidence to sustain that areas that provided depth refuge (short-term buffering or shelter against a particular disturbance episode) scale to refugia. In fact, the increasing frequency and severity of global impacts (warming and heatwaves) and regional human disturbances (e.g., pollution and fishing activities) cast doubt on the ability of MCEs to provide protection over the long-term (over multiple disturbances) (Bongaerts and Smith, 2019).

The notion of a "refuge" is quite broad in spatial and temporal terms, and the patterns and processes that define a refuge may operate at many different scales (Soares, 2020). Considering an evolutionary time scale (thousands of years), MCEs may have served as refugia during the Pleistocene glacial extremes. However, considering an ecological time scale (decades), the same MCEs may be unable to reseed the abutting shallow reefs, owing to species' demographic constraints that restrict dispersal, recruitment, and reproduction. Furthermore, refuges have different levels of biological organization, which range from the level of the gene to the entire ecosystem (Soares, 2020). The fact that one species occurs in both shallow and mesophotic reefs does not confirm that the mesophotic reef acts as a refuge for the entire reef ecosystem along the depth gradient. Rather, it suggests refuge for that particular species, which in itself requires further assessment and validation of vertical genetic connectivity (see Section 2.3).

Testing the DRRH at the community (assemblage) level also requires caution. When gene flow is detected across populations of shallow and deep areas, the set of subpopulations may act as a metapopulation, in which deep areas serve as refuges (Bongaerts et al., 2010 and references therein). The same rationale can be applied at the community level, if depth-generalist species connect shallow and deep reefs. Such connectivity assumes that the shallow-deep continuum encompasses a metacommunity, i.e., a set of local communities (coral reefs) linked by the dispersal of multiple interacting species (Morais and Santos, 2018).

Morais and Santos (2018) tested five predictions concerning the validity of the DRRH at the community level. The first prediction was that MCEs should host high gamma (total) biodiversity to be able to export species to shallow-water coral reefs. The second was that depth-generalist taxa should dominate the shallow ecosystems; otherwise, local extirpation in shallow areas would not be reverted by MCEs. Third, alpha (local) diversity should be greater in MCEs than in shallow ecosystems, given the reduced human pressures and natural disturbances in the twilight zone. Fourth, beta diversity (i.e., species turnover) in benthic communities should be smaller among shallow ecosystems than among MCEs because of the human-induced spread of a few disturbance-adapted species near the sea surface. Finally, to serve as refuges, MCEs should encapsulate the functional attributes (e.g., reproduction mode, type of skeleton, sexuality) observed in shallow reefs to ensure functional recovery of shallow-water coral reefs.

Morais and Santos (2018) suggested MCEs have limited potential to serve as refuges for SW Atlantic coral communities, which are dominated by two depth-generalist species (Siderastrea stellata and Montastraea cavernosa). In line with this, Rocha et al. (2018) also found limited support for the DRRH, based on the high turnover of species (e.g., fishes and corals) with increasing depth. Laverick et al. (2018), demonstrated that two-thirds of shallow species were present on MCEs. However, further analysis showed that this depth pattern was driven by geographic location and taxonomy. Community overlap between shallow and mesophotic reefs was estimated to be as low as $26 \%$ and as high as $97 \%$ for some reefs. Moreover, despite the evidence demon- 
strating the function of MCEs as short-term, ecological refuges; to date, there is little support that they comprise long-term refugia (Bongaerts and Smith, 2019). This reinforces that MCEs are not universal refuges (Bongaerts et al., 2017) and that they have a limited potential to reseed or replenish shallow-water species in distinct regions such as the Caribbean, Indo-Pacific (Rocha et al., 2018), and South Atlantic (Soares et al., 2019) seas.

Despite ongoing discussions regarding the DRRH - the outcomes of which are likely to vary by species and ecoregion (Bridge et al., 2013; Bongaerts et al., 2017) - we propose that the limited potential for MCEs to act as refuges is important for the conservation of both shallow and mesophotic ecosystems, fishery-targeted species (Lindfield et al., 2016) and regional reef diversity (Morais and Santos, 2018). For instance, MCEs can act as limited refuges for some species and as marine biodiversity reservoirs, if adequately protected. Moreover, MCEs could play a major role in maintaining important tropical seascapes and resources (Kahng et al., 2017; Muir et al., 2017; Muñoz et al., 2017), but our understanding of MCEs is so limited that informed decision-making is challenging. At the species level, MCEs may provide refuge for endangered, threatened, and declining reef species (Baker et al., 2016; Kahng et al., 2017). However, the potential for MCEs to provide refuge is dependent on the implementation of global policies, which provide them with adequate protection (Rocha et al., 2018; Soares et al., 2019).

\subsection{Horizontal and vertical connectivity}

MCEs are found in the intermediate ("twilight") zones of the ocean and are important for vertical and horizontal connectivity (Slattery et al., 2011; Hammerman et al., 2017). Horizontal connectivity is that between ecosystems and populations and can be distributed along one or more marine ecoregions. Vertical connectivity, on the other hand, is connectivity along a depth gradient and is important in the context of the DRRH and population maintenance. The role of MCEs in vertical connectivity has been supported by statistical models and studies of genetic and reef community composition (Holstein et al., 2016; Semmler et al., 2017). However, physiological changes (e.g., reproduction) in mesophotic populations, resulting from adaptation, may prevent full vertical connectivity with shallow habitats (Smith et al., 2016; Shlesinger et al., 2018).

Coral reproductive performance (e.g., spawning times, fecundity, oocyte sizes) decreases with depth; although some reef-building species are capable of reproducing at mesophotic depths, their contribution to the replenishment of shallow reefs is likely to be inconsequential (Shlesinger et al., 2018). It is possible that vertical connectivity exists for some reef species living in the upper $(30-50 \mathrm{~m})$ and mid $(50-70 \mathrm{~m})$ mesophotic zones that share some common species and are genetically connected with the shallow-water reefs (Semmler et al., 2017; Morais and Santos, 2018). However, the deeper mesophotic zone (70-150 m) tends to be populated by depth specific species that are uncommon in shallow waters (Baker et al., 2016; Pyle et al., 2016). Costantini et al. (2016) showed that shallow populations are genetically isolated from deeper ones and that at least for Mediterranean gorgonians, the DRRH is not valid. Environmental barriers such as pycnoclines may be key to understanding the lack of connectivity between shallow and deep populations of the same species (Costantini et al., 2011; Costantini et al., 2016). A slight difference in water mass density may lead to isolation or low gene flow between coral patches that are only a few meters apart, because of the buoyancy properties of coral propagules.

Horizontal connectivity is critical for the movement of species between distinct seascapes (Slattery et al., 2011; Hammerman et al., 2017). Pinheiro et al. (2017) suggested that patches of MCEs connect remote islands, seamounts to the inner continental shelf. In this way, lagoon MCEs (e.g. Great Barrier Reef, New Caledonia lagoons and Polynesian large atolls) (Bridge et al., 2019; Pichon, 2019) may be stepping stones for adult fish allowing them to find a refuge during reproductive or ontogenic migrations and, consequently, important for horizontal connectivity. The stable environmental conditions and presence of connecting currents characteristic of MCEs may be important factors influencing connectivity for sessile suspension feeding organisms (Rossi et al., 2008). As such, species inhabiting MCEs often show different patterns of horizontal connectivity unlike their counterparts in shallow waters. Moreover, MCEs can act as ecological corridors for species, even across areas traditionally considered to be biogeographical barriers (e.g., large freshwater plumes, ocean gyres; Soares et al., 2019). For example, the extensive MCE beneath the Amazon River plume (reviewed by Francini-Filho et al., 2018) is critically important for horizontal connectivity between Caribbean and Brazilian reefs. Similarly, a deep $(\sim 100 \mathrm{~m})$ coral habitat discovered along the southwestern Iberian coast in the Atlantic has provided evidence of gene flow with Mediterranean corals, despite the local complex oceanography (Boavida et al., 2016a, 2016b).

\subsection{Biomass of fishery resources}

Overfishing as a result of inadequate fishery policies and excessive pressure has resulted in a reduction in the biomass of fishery resources-primarily of high-trophic level species-in the shallow-water reefs (Muñoz et al., 2017; Arias-González et al., 2017). Because of the large distance from the shore and the water column depth, fishing effort in MCEs is generally lower than that in shallow-water reefs (Bridge et al., 2013; Sih et al., 2017). Moreover, fishing on MCEs are difficult especially using fixed nets (e.g. gill nets), drop lines as well as some hook and line techniques (e.g. bottom longlining). Consequently, some MCEs often have a higher biomass of fishery-targeted species than other areas (Lindfield et al., 2016; Abesamis et al., 2017). However, these stocks are very vulnerable to overfishing because the fish populations may be composed by species with slow growth, high longevity, low densities, and fragile populations (e.g., life history strategies and low connectivity along a depth gradient) (Pyle et al., 2019). Numerous seamount MCEs in the Indo-Pacific which have been nearly destroyed by bottom trawl fishing in the $1960-1990$ period. This was possible because these seamounts are not within the Economic Exclusive Zone of nearby countries and therefore suffer uncontrolled exploitation in the high seas (Gianni, 2004).

Unless effective fisheries management decisions are made, the increasing fishing pressure in MCEs is likely to exacerbate biomass collapse and species impoverishment in many tropical and subtropical regions (Rocha et al., 2018; Soares et al., 2019). We strongly recommend establishing MCEs as a global priority for conservation action, as a way to ensure the adequate protection of MCEs.

The relatively high fish biomass of some MCEs may also be because of their morphological (e.g., outer continental or insular shelves, low-gradient slopes, steep slopes, walls) and/or oceanographic features (Sherman et al., 2019) such as upwelling's that considerably increase fish biomass. Bastos et al. (2013) described the geomorphological features of MCEs, which include banks, paleochannels, submerged pinnacles, and coalescent structures with sinkhole-like depressions. These features may enhance fish biomass and productivity in the MCEs found in the SW Atlantic. In the waters of the NW Atlantic, the geomorphology of MCEs was found to be inherited from a variety of pre-existing geological structures of highly diverse origins (Locker et al., 2010). Notably, mesophotic species richness correlates with live coral cover, as the abundance of crevices and ledges promotes a high abundance of cryptic species (e.g., invertebrates, basslets, squirrel fishes, and gobies) and large demersal fishes (reviewed in Kahng et al., 2010; Boavida et al., 2016a, 2016b). 


\subsection{Biological diversity: endemism and poorly known biodiversity}

MCEs (and similar systems in the twilight zone) possess a unique biodiversity that includes depth-adapted specialist species (Bongaerts et al., 2015; Rocha et al., 2018). A robust comparison of species overlap between MCEs and shallow reef fishes in Palau, Papua New Guinea and Fiji was recently provided (Pyle and Copus, 2019). Whereas the pairwise overlap of shallow reef species ranges from $50 \%$ to $64 \%(40 \%$ for all three localities), the overlap among MCE fish species is 6.1-9.4\% (3.8\% for all three localities). This depth pattern indicates that MCEs fishes tend to have higher rates of endemism than shallow reef species (Pyle and Copus, 2019). The endemic reef fish found in the Caribbean Sea (Tornabene et al., 2016), Australia (Sih et al., 2017), Hawaii (Kosaki et al., 2017), and Brazil (Pinheiro et al., 2017) confirm this pattern. Furthermore, new species, endemic sponges (Baker et al., 2016; Pomponi et al., 2019), and other reef marine invertebrates have also recently been described (Leal et al., 2017). Pinheiro et al. (2017) proposed that South Atlantic seamount-endemic fish species evolved recently during a period characterized by changes in sea-level, as a result of intermittent connectivity caused by repeated aerial exposure of seamounts. This may explain why over $90 \%$ of fish in the Brazilian Vitória-Trindade seamount Chain are endemic ( $11 \%$ of which were only recently discovered; Pinheiro et al., 2015).

Even in areas that are relatively well-studied (e.g., the temperate coast of Europe), recent explorations into the deeper realms have revealed unexpected important coral communities and associated biota. For example, along the southwestern Iberian coast, temperate mesophotic ecosystems have sheltered long-lived corals as a result of the protective "roughness" of the terrain (Boavida et al., 2016a, 2016b). Mixed hard coral, gorgonians, sponge forests, and a mosaic of calcareous algae, bryozoans, and ophiuroids dominate the 40-50 m deep zone. At $60 \mathrm{~m}$, zoanthids that are $3 \mathrm{~m}$ tall become abundant. Deeper still at $100 \mathrm{~m}$, precious red corals dominate the assemblages, punctuated by rarer black corals (Fig. 2).

The recent findings summarized in this review highlight the importance of twilight ecosystems as biodiversity hotspots of unique, rare, and endemic species. However, the ongoing discovery of new species confirms that we are still in the early stages of the process to characterize MCEs. Hence, conclusions about geographic and depth endemism must be interpreted with caution (Turner et al., 2019). With the con- tinued exploration of mesophotic ecosystems, some reef species currently labeled as endemic will likely be discovered elsewhere. Furthermore, it is predicted that the exploration of highly diverse and under-studied locations, such as the Coral Triangle and the South Atlantic Ocean will provide new and much-needed knowledge of MCEs.

\subsection{Ecosystem goods and services (EGS)}

Globally, coral reefs are increasingly important providers of EGS (Costanza et al., 1997, 2014). In just two decades, there has been a 44-fold increase in the estimated value of EGS provided by shallow-water coral reefs, increasing from approximately 8000 to 352,000 USD ha $^{-1}$ year $^{-1}$ (Costanza et al., 2014; Paoli et al., 2017). Estimating the value of MCEs, both economically and intrinsically (Batavia and Nelson, 2017), is not trivial, particularly in global assessments. While MCEs provide a number of EGS that are also provided by shallow coral ecosystems (e.g., nursery effects and importance for biogeochemical cycles), they also provide distinct EGS (Holstein et al., 2019). For example, MCEs are potential refuges and carbon sinks (Bridge et al., 2013; Loya et al., 2016). In fact, the most neglected ecosystem service provided by mesophotic animal forests is their carbon sink function (Rossi, 2013; Rossi et al., 2017).

MCEs also provide protection from storms and are important potential sources of biotechnological products and fisheries resources (Loya et al., 2016; Holstein et al., 2019). We believe that the range and value of the EGS provided by MCEs justify their protection through the implementation of appropriate policies (Rocha et al., 2018; Soares et al., 2019). Furthermore, we believe that further research must be conducted to understand how the cumulative effect of human stressors affects the EGS provided by MCEs. Only then will we be in a position to discuss the challenges faced by MCEs and define the actions to improve ocean governance in the twilight zone (Baker et al., 2016).

\section{Ocean conservation: establishment of protection of MCEs}

In this review, we outline why global conservation policies must focus on heterogeneous set of MCEs. MCEs contain high levels of biodiversity; mesophotic reefs, rhodolith beds, black coral, octocoral forests, and sponge aggregations are all important and distinct seascapes. MCEs are not homogeneous systems globally, but cover a number of marginal ecosystems which have distinct characteristics (species richness, functional diversity, complexity, and endemism level) that need further research and high-resolution mapping overseas.
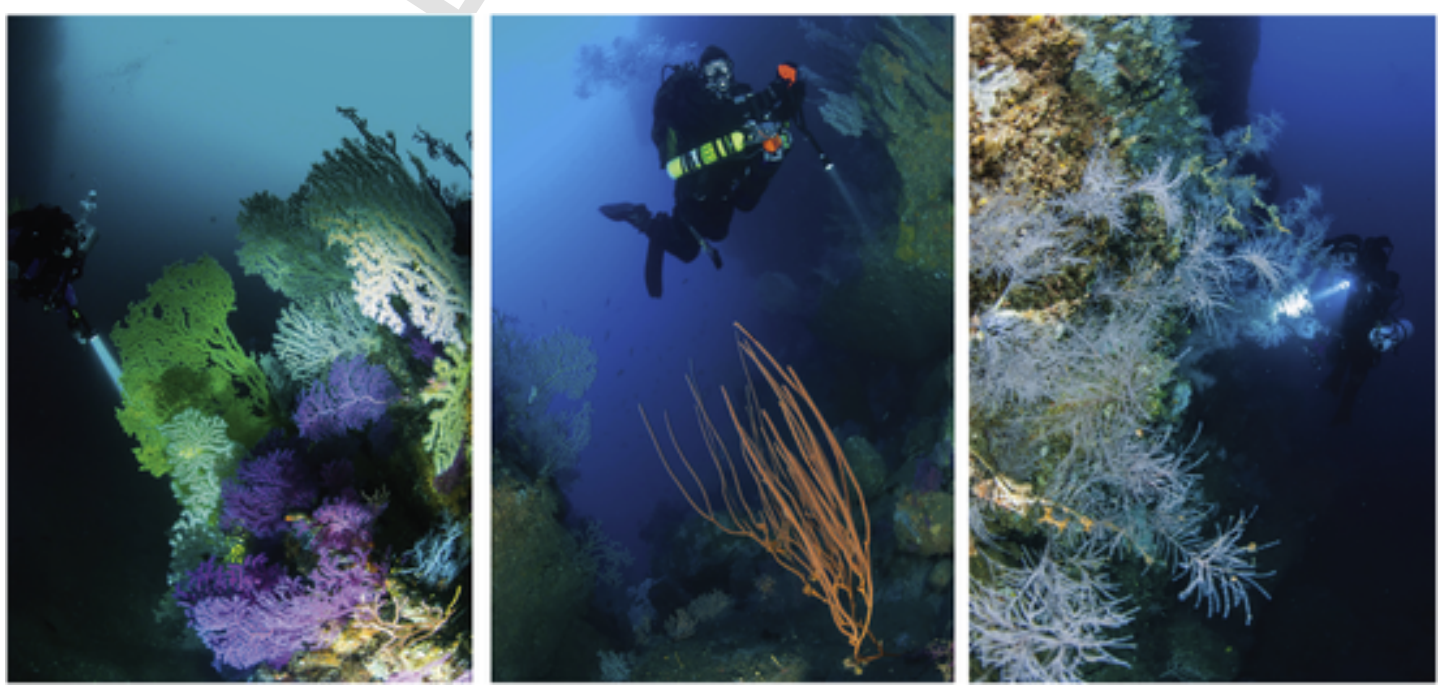

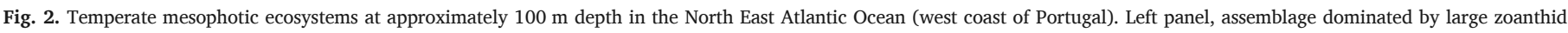
and octocorals; center panel, a rare giant gorgonian; right panel, a rarer black coral garden. Image credits: Armando Ribeiro. 
MCEs are also key contributors to the so-called good environmental status (European Union Marine Strategy Framework Directive) of the oceans. To date, some measures have been put in place to protect threatened species (mostly corals and fishes), which primarily include restrictions on fisheries exploitation and the aquarium trade (Aguilar et al. 2017; Smith et al., 2019). In addition, measures to control invasive species in MCEs, such as culling and trapping, are increasingly being adopted. However, the effectiveness of these measures is debatable, and in the case of the invasive species, the lionfish, there is little evidence to suggest that these controls mitigate its effects (Andradi-Brown, 2019). Moreover, while species-specific protection is important and needs to be improved upon, if the conservation of MCEs is to be effective, ecosystem-level approaches and most critically, the spatial management of human activities must be implemented (Fig. 3).

A number of the seascapes found in MCEs are listed as "vulnerable marine ecosystems," "sensitive habitats," or "essential fish habitats" (Aguilar et al. 2017). However, broader legal tools are required at the local, regional, and international level to effectively protect the distinct seascapes that have been identified in the mesophotic zone (Soares et al., 2019). Despite this, many countries still have not provided data on the existence of mesophotic ecosystems in their waters, and even in the cases where MCE data is available, very few countries have taken the management actions and high-resolution mapping required to preserve these important ecosystems (Aguilar et al. 2017).

Knowledge of the structure, function and resilience of MCEs is scarce (Turner et al., 2017). However, the characteristics of MCEs indicate that they are ecologically and biologically significant marine areas that require protection. Therefore, the precautionary principle of environmental law should be implemented to protect the relevant EGS and mesophotic areas of high biological importance (Smythe, 2017; Johnson et al., 2018). This protection can be achieved through the creation of MPAs, by regulating fisheries and by implementing large marine spatial planning (LMSP) (Fig. 3).

LMSP includes ocean zoning (OZ) and the protection of vulnerable marine ecosystems (e.g., through the designation of no-take zones). OZ can be used to regulate the anthropogenic activities (and other threats) that have direct effects on MCEs, such as fishing (Morais and Maia, 2017; Rocha et al., 2018), deployment of submarine cables, invasive species (Andradi-Brown, 2019), mining, and oil and gas activities (Silva et al., 2016; Frometa et al., 2017; Soares et al., 2020). Conservation strategies that utilize OZ and LMSP include the designa- tion of fishing closures, rigorous environmental licensing, and surveillance of shipping lines (Baker et al., 2016; Soares et al., 2019, 2020) (Fig. 3). However, in order for such protection measures to be adopted, it is imperative to determine how to translate scientific knowledge into resources that are accessible for conservation practitioners. Asking the question "what are the important messages required to inform stakeholders?" is a good way to begin addressing this issue (Turner et al., 2019).

In the context of OZ and LMSP (Agardy et al., 2011), adapting existing MPAs for the conservation of MCEs is an important strategy. There are two ways this can be achieved: (1) by adjusting management objectives when MCEs are already included in existing MPAs or (2) by creating or expanding existing MPAs to protect MCEs, using systematic conservation planning (as defined by Margules and Pressey, 2000). Regarding the first option, while some MCEs are legally included within the boundaries of existing MPAs, the management and conservation objectives for these areas often do not address MCEs directly because they are mostly focused on the shallow reefs (Soares et al., 2019; Turner et al., 2019). This can result in endemic MCE species or vulnerable habitats being left outside of the scope of the MPA's direct protection. As such, it is essential to update the management plans of existing MPAs to include specific actions for MCEs, for example, to reconcile economic activities (e.g., through the implementation of fishing closures) and improve MCE environmental monitoring and surveillance (Turner et al., 2019).

The second option for adapting existing MPAs for the conservation of MCEs involves the discovery of MCEs that are not yet managed by MPAs (Bridge et al., 2013; Moura et al., 2013; Turner et al., 2017, 2019). Existing networks of MPAs (e.g., the Indo-Pacific MPAs that cover shallow-water reefs; Bridge et al., 2013) can be expanded to include MCEs, or alternatively, new MPAs can be created (e.g., in the Great Amazon Reef; Francini-Filho et al., 2018). Mapping and identifying (Margules and Pressey, 2000) vulnerable MCEs is necessary to design and prioritize MPAs that protect the important living marine resources and ensure the maintenance of ecosystem services. However, vulnerable habitats are not always designated as MPAs because of conflict between conservation goals and human socioeconomic activities (e.g., fishing, mining for petroleum and gas). This was demonstrated by Lindegren et al. (2018) who highlighted that neither the world's most diverse nor most productive ecosystems are currently the most protected.

\section{Human impacts}

1. Fishing

2. Climate change

3. Oil and gas exploration

4. Invasive species

5. Marine debris

6. Mining

\section{Scientific priorities}

1. Diversity and distribution

2. Horizontal and vertical connectivity

3. Ecosystem services

4. Education and scientific outreach

5. Biology and ecology of the major species

6. High-resolution mapping of MCEs

Management priorities

1.Marine spatial planning

2. Environmental licensing

3. Marine protected areas

4. Ocean zoning

5 . Fishing closures and regulation

6. Reduce carbon emissions

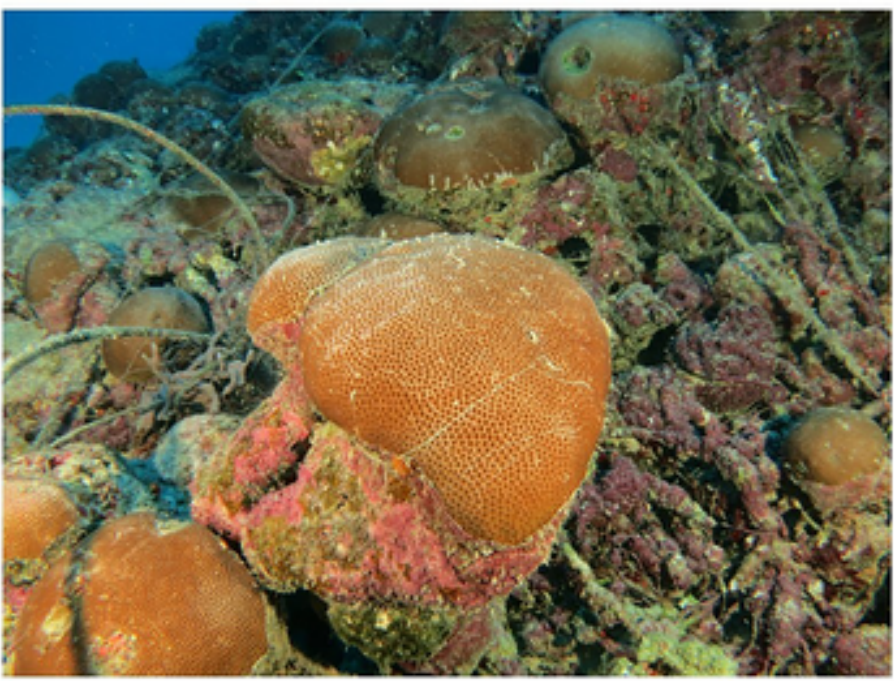

Fig. 3. Mesophotic coral ecosystems: human effects and scientific and management strategies that must be addressed to make them a conservation priority. 
Knowledge of the size, connectivity, spacing, and shape of MPAs, as well as of the health status and resilience of MCEs, is required to inform the conservation actions discussed in the previous paragraphs (Cánovas-Molina et al., 2016; Rodríguez-Rodríguez et al., 2016; Rocha et al., 2018; Soares 2018 ). As such, to devise effective governance plans, there is an urgent need to understand the ecological role of MCEs, particularly in areas where environmental change as a result of climate change and/or local stressors is occurring faster than the system can recover. It is also important to build networks of MPAs (Roberts et al., 2018), which include MCEs. However, regardless of whether actions are local, regional, or global, MPAs will be more effective if shallow and mesophotic coral reefs are protected together (e.g., Morais and Santos, 2018).

Systematic conservation planning, which aids in identifying high-priority zones, is a useful tool for designating MPA networks (Margules and Pressey, 2000). However, because there are additional challenges in assessing remote and deep ecosystems such as MCEs (Turner et al., 2019), key indicators such as biodiversity, endemism, genetic connectivity, and EGS should be monitored, standardized, and used to generate protocols for evaluating the progress of MCE conservation. It has been suggested that thermal stress and ocean acidification are the greatest existential threats to MCEs (Smith et al., 2019). However, there are also many local disturbances that are amenable to the resilient-based management (Mcleod et al., 2019) strategies described in this manuscript. Worryingly, continued business-as-usual emissions will likely further disrupt many shallow-water reefs and MCEs. Therefore, we believe that immediate action must be taken to decarbonize the economy, enhance carbon sinks, and ensure the effective conservation of these irreplaceable ecosystems.

\section{Conclusions}

In this review we have demonstrated that MCEs are significant in terms of their high biodiversity and that they represent a natural heritage for mankind. Furthermore, we have argued that MCEs must be protected to avoid unnecessary declines in biodiversity and in the ecosystem goods and services on which the society depends. In recent years, a growing body of evidence has led to several descriptions of MCEs around the world (Hinderstein et al., 2010; Bridge et al., 2013; Baker et al., 2016; Loya et al., 2016; Kahng et al., 2014, 2017; Turner et al., 2019). In this review, we have identified the key characteristics that support the inclusion of MCEs in global conservation policies (summarized in Table 1).

In order to address the challenges associated with protecting MCEs, the right questions (Turner et al., 2019) need to be identified, for example, questions relating to the similarities and dissimilarities between mesophotic and shallow coral ecosystems. There is empirical evidence that supports the hypothesis that protecting mesophotic reefs will also help to conserve shallow-water species (Laverick et al., 2018). Furthermore, it is important to note that without protecting mesophotic-specialist assemblages, connectivity between shallow and mesophotic reefs would be compromised, which would affect the potential refuge dynamics between these two important ecosystems. The unique biodiversity found exclusively in waters deeper than $30 \mathrm{~m}$ warrants protection in its own right, and we propose that further research into these relatively ignored taxa and geographic regions will help improve the resilient-based management strategies (McLeod et al., 2019) proposed in this manuscript. Because beta diversity may be high, especially in shallow-water tropical coral reefs, and many species are specialized in mesophotic depths (Morais and Santos, 2018; Rocha et al., 2018), conservation and management actions should integrate the protection of shallow and MCEs to maintain the regional (gamma) reef diversity. MCEs are important marine ecosystems that can no longer be left unattended.

\section{Uncited references}

Jones et al., 1994

Mumby, 2009

Rossi, 2013

Soares, 2018

\section{Declaration of competing interest}

The authors declare that they have no known competing financial interests or personal relationships that could have appeared to influence the work reported in this paper.

\section{Acknowledgments}

MOS was supported by CAPES-PRINT Program, Projeto CORAL VIVO, CNPQ (Grant numbers 233808/2014-0 and Process 307061/ 2017-5), and INCT AmbTropic (CNPq/CAPES). SR was funded with a Marie Curie International Outgoing Fellowship (ANIMAL FOREST HEALTH, Grant Agreement Number 327845) and P-SPHERE (COFUND Marie Curie, Grant Agreement Number 665919). BAS was supported by CNPQ (grant number 310340/2016-0).

\section{References}

Abaya, L M, Wiegner, T N, Beets, J P, Colbert, S L, Carlson, K M, Kramer, K L, 2018 Spatial distribution of sewage pollution on a Hawaiian coral reef. Mar. Pollut. Bull. 130, 335-347. doi:10.1016/j.marpolbul.2018.03.028.

Abesamis, R A, Langlois, T, Birt, M, Thillainath, E, Bucol, A A, Arceo, H O, Russ, G R, 2017 Benthic habitat and fish assemblage structure from shallow to mesophotic depths in a storm-impacted marine protected area. Coral Reefs 37, 81-97. doi:10.1007/ s00338-017-1635-0.

Agardy, T, di Sciara, G N, Christie, P, 2011. Mind the gap: addressing the shortcomings of marine protected areas through large scale marine spatial planning. Mar. Policy 35 (2), 226-232. doi:10.1016/j.marpol.2010.10.006.

Andradi-Brown, D A, 2019. Invasive lionfish (Pterois volitans and P. miles): distribution, impact, and management. In: Loya, Y, Puglise, K, Bridge, T (Eds.), Mesophotic Coral Ecosystems. In: Coral Reefs of the World. Springer, Cham, pp. 931-941. doi:10.1007/ 978-3-319-92735-0_48.

Arias-González, J E, Riversa-Sosa, A, Zaldívar-Rae, J, Alva-Basurto, C, Cortés-Useche, C, 2017. The animal forest and its socio-ecological connections to land and coastal ecosystems. In: Rossi, S, Bramanti, L, Gori, A, Orejas, C (Eds.), Marine Animal Forests. Springer, Cham, pp. 1209-1240. doi:10.1007/2F978-3-319-21012-4_33.

Asaad, I, Lundquist, C J, Erdmann, M V, Costello, M J, 2017. Ecological criteria to identify areas for biodiversity conservation. Biol. Conserv. 213, 309-316. doi:10.1016/ j.biocon.2016.10.007.

Baker, E, Puglise, K, Harris, P T, 2016. Mesophotic Coral Ecosystems: A Lifeboat for Coral Reefs? The United Nations Environment Programme (UNEP) and GRID-Arendal, Nairobi and Arendal 98p. Available in. http://www.unep.org/ourplanet/may-2016/ unep-publications/mesophotic-coral-ecosystems.

Ballesteros, L V, Matthews, J L, Hoeksema, B W, 2018. Pollution and coral damage caused by derelict fishing gear on coral reefs around Kao Tao, Gulf of Thailand. Mar. Pollut. Bull. 135, 1107-1116. doi:10.1016/j.marpolbul.2018.08.033.

Bastos, A C, Moura, R L, Amado-Filho, G M, D'Agostini, D P, Secchin, N A, Francini-Filho, R B, Güth, A Z, Sumida, P Y G, Mahiques, M M, Thompson, F L, 2013. Buracas: novel and unusual sinkhole-like features in the Abrolhos Bank. Cont. Shelf Res. 70, 118-125. doi:10.1016/j.csr.2013.04.035.

Batavia, C, Nelson, M P, 2017. For goodness sake! What is intrinsic value and why should we care? Biol. Conserv. 209, 366-376. doi:10.1016/j.biocon.2017.03.003.

Bednarz, V N, Grover, R, Ferrier-Pagès, C, 2020. Elevated ammonium delays the impairment of the coral-dinoflagellate symbiosis during labile carbon pollution. Aquat. Toxicol. 218, 105360. doi:10.1016/j.aquatox.2019.105360.

Bigus, P, Tobiszewski, M, Namiesnik, J, 2014. Historical records of organic pollutants in sediment cores. Mar. Pollut. Bull. 78 (1-2), 26-42. doi:10.1016/ j.marpolbul.2013.11.008.

Boavida, J, Paulo, D, Aurelle, D, Arnaud-Haond, S, Marschal, C, Reed, J, Gonçalves, J M S, Serrao, E A, 2016. A well-kept treasure at depth: precious red coral rediscovered in Atlantic deep coral gardens (SW Portugal) after 300 years. PLoS One 11 (2016), e0147228. doi:10.1371/journal.pone.0147228.

Boavida, J, Assis, J, Reed, J, Serrão, E A, Gonçalves, J M S, 2016. Comparison of small remotely operated vehicles and diver-operated video of circalittoral benthos. Hydrobiologia 766, 247-260. doi:10.1007/s10750-015-2459-y.

Bongaerts, P, Smith, T B, 2019. Beyond the "deep reef refuge" hypothesis: a conceptual framework to characterize persistence at depth. In: Loya, Y, Puglise, K, Bridge, T (Eds.), Mesophotic Coral Ecosystems. In: Coral Reefs of the World. Springer, Cham, pp. 881-895. doi:10.1007/978-3-319-92735-0_45. 
Bongaerts, P, Ridgway, T, Sampayo, E M, Hoegh-Guldberg, O, 2010. Assessing the "deep reef refugia" hypothesis: focus on Caribbean reefs. Coral Reefs 29, 309-327. doi:10.1007/s00338-009-0581-x.

Bongaerts, P, Frade, P R, Hay, K B, Englebert, N, Latijnhouwers, K R W, Bak, R P M, Vermeij, M J A, Hoegh-Guldberg, O, 2015. Deep down on a Caribbean reef: lower mesophotic depths harbor a specialized coral-endosymbiont community. Sci. Rep. 5, 7652. doi:10.1038/srep07652.

Bongaerts, P, Riginos, C, Brunner, R, Englebert, N, Smith, S R, Hoegh-Guldberg, O, 2017. Deep reefs are not universal refuges: reseeding potential varies among coral species. Sci. Adv. 3 (2), e1602373. doi:10.1126/sciadv.1602373.

Bramanti, L, Movilla, J, Guron, M, Calvo, E, Gori, A, Dominguez-Carrió, C, Grinyó, J, Lopez-Sanz, A, Martinez-Quintana, A, Pelejero, C, Ziveri, P, Rossi, S, 2013 Detrimental effects of ocean acidification on the economically importan Mediterranean red coral (Corallium rubrum). Glob. Chang. Biol. 19, 1897-1908. doi:10.1111/gcb.12171.

Bridge, T C L, Hughes, T P, Guinotte, J M, Bongaerts, P, 2013. Call to protect all coral reefs. Nat. Clim. Chang. 3, 528-530. doi:10.1038/nclimate1879.

Bridge, T C L, Beaman, R J, Bongaerts, P, Muir, P R, Ekins, M, Sih, T, 2019. The great barrier reef and coral sea. In: Loya, Y, Puglise, K, Bridge, T (Eds.), Mesophotic Coral Ecosystems. In: Coral Reefs of the World. Springer, Cham, pp. 351-367. doi:10.1007/ 978-3-319-92735-0 20.

Bruno, J F, Bates, A E, Cacciapaglia, C, Pike, E P, Amstrup, S C, Hooidonk, R V, Henson, S A, Aronson, R B, 2018. Climate change threatens the world's marine protected areas. Nat. Clim. Chang. 8, 499-503. doi:10.1038/s41558-018-0149-2.

Cai, Y, Wang, X, Wu, Y, Li, Y, Ya, M, 2016. Over 100-year sedimentar record of polycyclic aromatic hydrocarbons (PAHs) and organochlorine compounds (OCs) in the continental shelf of the East China Sea. Environ. Pollut. 219, 774-784. doi:10.1016/ j.envpol.2016.07.053.

Cánovas-Molina, A, Montefalcone, M, Bavestrello, G, Cau, A, Bianchi, C K, Morri, C, Canese, S, Bo, M, 2016. A new ecological index for the status of mesophotic assemblages in the mediterranean based on ROV photography and video footage. Cont. Shelf Res. 121, 13-20. doi:10.1016/j.csr.2016.01.008.

Costantini, F, Rossi, S, Pintus, E, Cerrano, C, Gili, J M, Abbiati, M, 2011. Low connectivity and declining genetic variability along a depth gradient in Corallium rubrum populations. Coral Reefs 30 (4), 991-1003. doi:10.1007/s00338-011-0771-1.

Costantini, F, Gori, A, Lopez-González, P, Bramanti, L, Rossi, S, Gili, J M, Abbiati, M, 2016 Limited genetic connectivity between gorgonian morphotypes along a depth gradient. PLoS One 11 (8), e0160678. doi:10.1371/journal.pone.0160678.

Costanza, R, dArge, R, de Groot, R, Farber, S, Grasso, M, Hannon, B, Limburg, K, Naeem, S Oneill, R V, Paruelo, J, Raskin, R G, Sutton, P, van den Belt, M, 1997. The value of the world's ecosystem services and natural capital. Nature 387, 253-260. doi:10.1038/ 387253a0.

Costanza, R, de Groot, R, Sutton, P, der Ploeg, S V, Anderson, S J, Kubiszewiski, I, Farber, S, Turner, R K, 2014. Changes in the global value of ecosystem services. Glob. Environ. Chang. 26, 152-158. doi:10.1016/j.gloenvcha.2014.04.022.

Frade, P R, Bongaerts, P, Englebert, N, Rogers, A, Gonzalez-Rivero, M, Hoegh-Guldberg, O, 2018. Deep reefs of the Great Barrier Reef offer limited thermal refuge during mass coral bleaching. Nat. Commun. 9, 3447. doi:10.1038/s41467-018-05741-0.

Francini-Filho, R B, Asp, N, Siegle, E, Hocevar, J, Lowyck, K, Davila, N, Vasconcelos, A, Baitelo, R, De Rezende, C E, Omachi, C Y, Thompson, C T, 2018. Perspectives on the Great Amazon Reef: extension, biodiversity and threats. Front. Mar. Sci. 5, 142. doi:10.3389/fmars.2018.00142.

Frometa, J, DeLorenzo, M E, Pisarski, E C, Etnoyer, P J, 2017. Toxicity of oil and dispersant on the deep water gorgonian octocoral Swiftia exserta, with implications for the effects of Deepwater Horizon oil spill. Mar. Pollut. Bull. 122, 91-99. doi:10.1016/ j.marpolbul.2017.06.009.

Gianni, M, 2004. High Seas Bottom Trawl Fisheries and Their Impacts on the Biodiversity of Vulnerable Deep-sea Ecosystems: Options for International Action. IUCN International Union for Conservation of Nature and Natural Resources, Gland, Switzerland. http://www.iucn.org/themes/marine/pubs/pubs.htm. (Accessed 4 March 2020).

Gori, A, Viladrich, N, Gili, J M, Kotta, M, Cucio, C, Magni, L, Bramanti, L, Rossi, S, 2012. Reproductive cycle and trophic ecology in deep versus shallow populations of the mediterranean gorgonian Eunicella singularis (cap de creus, northwestern mediterranean sea). Coral Reefs 31, 823-837. doi:10.1007/s00338-012-0904-1.

Groves, S H, Holstein, D M, Enochs, I C, Kolodzeij, G, Manzello, D P, Brandt, M E, Smith, T B, 2018. Growth rates of Porites astreoides and Orbicella franksi in mesophotic habitats surrounding St. Thomas, US Virgin Islands. Coral Reefs 37, 345-354. doi:10.1007/ s00338-018-1660-7.

Hammerman, N M, Rivera-Vicens, R E, Galaska, M P, Weil, E, Appledoorn, R S, Alfaro, M, Schizas, N V, 2017. Population connectivity of the plating coral Agaricia lamarckii from southwest Puerto Rico. Coral Reefs 37, 183-191. doi:10.1007/s00338-017-1646-x.

Hinderstein, L M, Marr, J C A, Martinez, F A, Dowgiallo, M J, Puglise, K A, Pyle, R L, Zawada, D G, Appeldoorn, R, 2010. Theme section on 'mesophotic coral ecosystems: characterization, ecology and management'. Coral Reefs 29, 247-251. doi:10.1007/ s00338-010-0614-5.

Holstein, D M, Paris, C B, Vaz, A C, Smith, T B, 2016. Modeling vertical connectivity and mesophotic refugia. Coral Reefs 35 (1), 23-37. doi:10.1007/s00338-015-1339-2.

Holstein, D M, Fletcher, P, Groves, S H, Smith, T B, 2019. Ecosystems services of mesophotic coral ecosystems and a call for better accounting. In: Loya, Y, Puglise, K, Bridge, T (Eds.), Mesophotic Coral Ecosystems. In: Coral Reefs of the World. Springer, Cham, pp. 943-956. doi:10.1007/978-3-319-92735-0_49.

Hughes, T P, et al., 2018. Spatial and temporal patterns of mass bleaching of corals in the Anthropocene. Science 359 (3671), 80-83. doi:10.1126/science.aan8048.
Iglesias-Prieto, R, Beltran, V, LaJeunesse, T, Reyes-Bonilla, H, Thome, P, 2004. Different algal symbionts explain the vertical distribution of dominant reef corals in the eastern Pacific. Proc R Soc London Ser B 271, 1757-1763. doi:10.1098/rspb.2004.2757.

Jafarabadi, A R, Bakhtiari, A R, Toosi, A S, 2017. Comprehensive and comparative ecotoxicological and human risk assessment of polycyclic aromatic hydrocarbons (PAHs) in reef surface sediments and coastal seawaters of Iranian Coral Islands, Persian Gulf. Ecotoxicol. Environ. Saf. 145, 640-652. doi:10.1016/ j.ecoenv.2017.08.016

Jafarabadi, A R, Bakhtiari, A R, Mitra, S, Maisano, M, Cappelo, T, Jadot, C, 2019. First polychlorinated byphenyls (PCBs) monitoring in seawater, surface sediments and marine fish communities of the Persian Gulf: distribution, levels, congener profile and health risk assessment. Environ. Pollut. 253, 78-88. doi:10.1016/ j.envpol.2019.07.023.

Jafarabadi, A R, Dashtbozorg, M, Mitra, S, Bakhtiari, A R, Dehkordi, S M, Cappelo, T, 2019. Historical sedimentary deposition and ecotoxicological impact of aromatic biomarkers in sediment cores from ten coral reefs of the Persian Gulf, Iran. Sci. Total Environ. 696, 133969. doi:10.1016/j.scitotenv.2019.133969.

Johnson, D E, Froján, C B, Turner, P J, Weaver, P, Gunn, V, Dunn, D C, Halpin, P, Bax, N J, Dunstan, P K, 2018. Reviewing the EBSA process: improving on success. Mar. Policy 88, 75-85. doi:10.1016/j.marpol.2017.11.014.

Jones, C J, Lawton, J H, Shachak, M, 1994. Organisms as ecosystem engineers. Oikos 69 , 373-386. doi:10.1007/978-1-4612-4018-1_14.

Kahng, S E, Garcia-Sais, J R, Spalding, H L, Brokovich, E, Wagner, D, Weil, E, Hinderstein, L, Toonen, R J, 2010. Community ecology of mesophotic coral reef ecosystems. Coral Reefs 29, 255-275. doi:10.1007/s00338-010-0593-6.

Kahng, S E, Copus, J M, Wagner, D, 2014. Recent advances in the ecology of mesophotic coral ecosystems (MCEs). Curr. Opin. Environ. Sustain. 7, 72-81. doi:10.1016/ j.cosust.2013.11.019.

Kahng, S, Copus, J M, Wagner, D, 2017. Mesophotic coral ecosystems. In: Rossi, S (Ed.), Marine Animal Forests. Springer International Publishing, pp. 185-206. doi:10.1007/ 978-3-319-17001-54-

Kosaki, R K, Pyle, R L, Leonard, J C, Hauk, B B, Whitton, R K, Wagner, D, 2017. 100\% endemism in mesophotic reef fish assemblages at Kure Atoll, Hawaiian Islands. Mar. Biodivers. 47 (3), 783-784. doi:10.1007/s12526-016-0510-5.

Laverick, J H, Piango, S, Andradi-Brown, D A, Exton, D A, Bongaerts, P, Bridge, T C L, Lesser, M P, Pyle, R L, Slattery, M, Wagner, D, Rogers, A D, 2018. To what extent do mesophotic coral ecosystems and shallow reefs share species of conservation interest? A systematic review. Environ. Evid. 7, 15. doi:10.1186/s13750-018-0127-1.

Leal, C V, Moraes, F C, Froes, A M, Soares, A C, Oliveira, L S, Moreira, A P B, Thompson, F, Hajdu, E, 2017. Integrative taxonomy of Amazon Reefs' Arenosclera spp.: a new clade in the Haplosclerida (Demospongiae). Front. Mar. Sci. 4, 2017.00291. doi:10.3389/ fmars.2017.00291.

Lesser, M P, Slattery, M, Leichter, J J, 2009. Ecology of mesophotic coral reefs. J. Exp. Mar. Biol. Ecol. 375, 1-8. doi:10.1016/j.jembe.2009.05.009.

Lindegren, M, Holt, B G, Mackensie, B R, Rahbek, C, 2018. A global mismatch in the protection of multiple marine biodiversity components and ecosystem services. Sci. Rep. 8, 4099. doi:10.1038/s41598-018-22419-1.

Lindfield, S J, Harvey, E S, Halford, A R, Mcllwain, J L, 2016. Mesophotic depths as refuge areas for fishery-targeted species on coral reefs. Coral Reefs 35, 125-137. doi:10.1007/s00338-015-1386-8.

Locker, S D, Armstrong, R A, Battista, T A, Rooney, J J, Sherman, C, Zawada, D G, 2010. Geomorphology of mesophotic coral ecosystems: current perspectives on morphology, distribution, and mapping strategies. Coral Reefs 29 (2), 329-345. doi:10.1007/ s00338-010-0613-6.

Longenecker, K, Roberts, T E, Colin, P L, 2019. Papua New Guinea. In: Loya, Y, Puglise, K, Bridge, T (Eds.), Mesophotic Coral Ecosystems. In: Coral Reefs of the World. Springer, Cham, pp. 321-336. doi:10.1007/978-3-319-92735-0_18.

Loya, Y, Eyal, G, Treibitz, T, Lesser, M P, Appeldoorn, R, 2016. Theme section on mesophotic coral ecosystems: advances in knowledge and future perspectives. Coral Reefs 35, 1-9. doi:10.1007/s00338-016-1410-7.

Margules, C R, Pressey, R L, 2000. Systematic conservation planning. Nature 405, 243-253. doi:10.1038/35012251.

McLeod, E, Anthony, K R N, Mumby, P J, Maynard, J, Beeden, R, Graham, N A J, Heron, S F, Hoegh-Guldberg, O, Jupiter, S, MacGowan, P, Mangubhai, S, Marshall, P A, McClanahan, T R, Mcleod, K, Nystrom, M, Obura, D, Parker, B, Possingham, H P, Salm, R V, Tamelander, J, 2019. The future of resilience-based management in coral reef ecosystems. J. Environ. Manag. 233, 291-301. doi:10.1016/ j.jenvman.2018.11.034

Morais, R A, Maia, H A, 2017. Lush underwater forests in mesophotic reefs of the Gulf of Guinea. Coral Reefs 36 (1), 95. doi:10.1007/s00338-016-1523-Z

Morais, J, Santos, B A, 2018. Limited potential of deep reefs to serve as refuges for tropical Southwestern Atlantic corals. Ecosphere 9 (7), e02281. doi:10.1002/ecs2.2281.

Morais, J, Medeiros, A P M, Santos, B A, 2018. Research gaps of coral ecology in a changing world. Mar. Environ. Res. 140, 243-250. doi:10.1016/ j.marenvres.2018.06.021.

Moura, R L, Secchin, N A, Amado-Filho, G M, Francini Filho, R B, Freitas, M O, Minte-Vera, C V, Teixeira, J B, Thompson, F L, Dutra, G F, Sumida, P Y G, Guth, A Z, Lopes, R M, Bastos, A C, 2013. Spatial patterns of benthic megahabitats and conservation planning in the Abrolhos Bank. Cont. Shelf Res. 70, 109-117. doi:10.1016/j.csr.2013.04.036.

Muir, P R, Marshall, P A, Abdulla, A, Aguirre, J D, 2017. Species identity and depth predict bleaching severity in reef-building corals: shall the deep inherit the reef? Proc. R. Soc. B 284 (1864), 20171551. doi:10.1098/rspb.2017.1551. 
Mumby, P J, 2009. Phase shifts and the stability of macroalgal communities on Caribbean coral reefs. Coral Reefs 28 (3), 761-773. doi:10.1007/2Fs00338-009-0506-8.

Muñoz, R C, Buckel, C A, Whitfield, P E, Viehman, S, Clark, R, Taylor, J C, Degan, B P, Hickerson, E L, 2017. Conventional and technical diving surveys reveal elevated biomass and differing fish community composition from shallow and upper mesophotic zones of a remote United States coral reef. PLoS One 12 (11), e0188598. doi:10.1371/journal.pone.0188598.

Paoli, C, Montefalcone, M, Morri, C, Vassallo, P, Bianchi, C K, 2017. Ecosystem functions and services of the marine animal forests. In: Rossi, S, Bramanti, L, Gori, A, Orejas, C (Eds.), Marine Animal Forests. Springer, Cham, pp. 1-42. doi:10.1007/ 2F978-3-319-17001-5_38-1.

Pichon, M, 2019. French Polynesia. In: Loya, Y, Puglise, K, Bridge, T (Eds.), Mesophotic Coral Ecosystems. In: Coral Reefs of the World. Springer, Cham, pp. 425-443. doi:10.1007/978-3-319-92735-0 24.

Pinheiro, H T, Mazzei, E, Moura, R L, Amado-Filho, G M, Carvalho-Filho, A, Braga, A C, Costa, P A S, Ferreira, B P, Ferreira, C E L, Floeter, S R, Francini-Filho, R B, Gasparini, J L, Macieira, R M, Martins, A S, Olavo, G, Pimentel, C R, Rocha, L A, Sazima, I, Simon, T, Teixeira, J B, Xavier, L B, Joyeux, J C, 2015. Fish biodiversity of the Vitória-Trindade Seamount Chain, Southwestern Atlantic: an updated database. PLoS One 10, e0118180. doi:10.1371/journal.pone.0118180.

Pinheiro, H T, Bernardi, G, Simon, T, Joyeux, J C, Macieira, R M, Gasparini, J L, Rocha, C, Rocha, L A, 2017. Island biogeography of marine organisms. Nature 549, 82-85. doi:10.1038/nature23680.

Pomponi, S A, Diaz, M C, Soest, R W M V, Bell, L J, Busutil, L, Gochfeld, D J, Kelly, M, Slattery, M, 2019. Sponges. In: Loya, Y, Puglise, K, Bridge, T (Eds.), Mesophotic Coral Ecosystems. In: Coral Reefs of the World. Springer, Cham, pp. 563-588. doi:10.1007/ 978-3-319-92735-0_32.

Pyle, R L, Copus, J M, 2019. Mesophotic coral ecosystems: introduction and overview. In: Loya, Y, Puglise, K, Bridge, T (Eds.), Mesophotic Coral Ecosystems. In: Coral Reefs of the World. Springer, Cham, pp. 3-27. doi:10.1007/978-3-319-92735-0_1.

Pyle, R L, Boland, R, Bolick, H, Bowen, B W, Bradley, C J, Kane, C, Kosaki, R K, Langston, R, Longenecker, K, Montgomery, A, Parrish, F A, Popp, B N, Rooney, J, Smith, C M, Wagner, D, Spalding, H L, 2016. A comprehensive investigation of mesophotic coral ecosystems in the Hawaiian Archipelago. Peer J. 4, e2475. doi:10.7717/peerj.2475.

Pyle, R L, Kosaki, R K, Pinheiro, H T, Rocha, L A, Whitton, R K, Copus, J M, 2019. Fishes: biodiversity. In: Loya, Y, Puglise, K, Bridge, T (Eds.), Mesophotic Coral Ecosystems. In: Coral Reefs of the World. Springer, Cham, pp. 749-777. doi:10.1007/ 978-3-319-92735-0 40.

Ricolleau, A, Floquet, N, Devidal, J L, Bodnar, R J, Perrin, J, Garrabou, J, Harmelin, J G, Costantini, F, Boavida, J R, Vielzeuf, D, 2019. Lead (Pb) profiles in red coral skeletons as high resolution records of pollution in the Mediterranean Sea. Chem. Geol. 525, 112-124. doi:10.1016/j.chemgeo.2019.07.005.

Roberts, K E, Valkan, R S, Cook, C N, 2018. Measuring progress in marine protection: a new set of metrics to evaluate the strength of marine protected areas networks. Biol. Conserv. 219, 20-27. doi:10.1016/j.biocon.2018.01.004.

Rocha, L A, Pinheiro, H T, Sheperd, B, Papastamatiou, Y P, Luiz, O J, Pyle, R L, Bongaerts, $\mathrm{P}, 2018$. Mesophotic coral ecosystems are threatened and ecological distinct from shallow water reefs. Science 361 (6399), 281-284. doi:10.1126/science.aaq1614.

Rodríguez-Rodríguez, D, Rodríguez, J, Blanco, J M, Malak, D A, 2016. Marine protected area design patterns in the Mediterranean Sea: implications for conservation. Mar. Pollut. Bull. 110 (1), 315-342. doi:10.1016/j.marpolbul.2016.06.044.

Rossi, S, 2013. The destruction of the "animal forests" in the oceans: towards an over-simplification of the benthic ecosystems. Ocean Coast. Manag. 84, 77-85. doi:10.1016/j.ocecoaman.2013.07.004.

Rossi, S, Tsounis, G, Orejas, C, Padrón, T, Gili, J M, Bramanti, L, Teixidó, N, Gutt, J, 2008. Survey of deep dwelling red coral (Corallium rubrum) populations at Cap de Creus (NW Mediterranean). Mar. Biol. 154, 533-545. doi:10.1007/s00227-008-0947-6.

Rossi, S, Bramanti, L, Gori, A, Orejas, C, 2017. Animal forests of the world: an overview. In: Rossi, S, Bramanti, L, Gori, A, Orejas, C (Eds.), Marine Animal Forests. Springer, Cham, pp. 1-28. doi:10.1007/978-3-319-21012-4_1.

Schyff, V V D, Yive, N S C K, Bouwman, H, 2020. Metal concentrations in corals from South Africa and the Mascarene Basin: a first assessment for the Western Indian Ocean. Chemosphere 239, 124784. doi:10.1016/j.chemosphere.2019.124784.

Semmler, R F, Hoot, W C, Reaka, M L, 2017. Are mesophotic coral ecosytems distinct communities and can they serve as refugia for shallow reefs? Coral Reefs 36 (2), 433-444. doi:10.1007/s00338-016-1530-0.

Sherman, C E, Locker, S D, Webster, J M, Weinstein, J M, 2019. Geology and geomorphology. In: Loya, Y, Puglise, K, Bridge, T (Eds.), Mesophotic Coral Ecosystems. In: Coral Reefs of the World. Springer, Cham, pp. 849-878. doi:10.1007/ 978-3-319-92735-0 44.

Shlesinger, T, Grinblat, M, Rapuano, H, Amit, T, Loya, Y, 2018. Can mesophotic reefs replenish shallow reefs? Reduced coral reproductive performance casts a doubt. Ecology 99 (2), 421-437. doi:10.1002/ecy.2098.

Shoham, E, Benayahu, Y, 2017. Higher species richness of octocorals in the upper mesophotic zone in Eilat (Gulf of Aqaba) compared to shallower reef zones. Coral Reefs 36 (1), 71-81. doi:10.1007/s00338-016-1528-7.

Sih, T L, Cappo, M, Kingsford, M, 2017. Deep-reef fish assemblages of the Great Barrier Reef Shelf-Break (Australia). Sci. Rep. 7, 10886. doi:10.1038/s41598-017-11452-1.

Silva, M, Etnoyer, P J, MacDonald, I R, 2016. Coral injuries observed at Mesophotic reefs after the Deepwater Horizon oil discharge. Deep-Sea Res. II Top. Stud. Oceanogr. 129, 96-107. doi:10.1016/j.dsr.2.2015.05.013.
Slattery, M, Lesser, M P, Brazeau, D, Stokes, M D, Leichter, J J, 2011. Connectivity and stability of mesophotic coral reefs. J. Exp. Mar. Biol. Ecol. 408 (1-2), 32-41. doi:10.1016/j.jembe.2011.07.024.

Smith, T B, Gyory, J, Brandt, M E, Miller, W J, Jossart, J, Nemeth, R S, 2016. Caribbean mesophotic coral ecosystems are unlikely climate change refugia. Glob. Chang. Biol. 22 (8), 2756-2765. doi:10.1111/gcb.13175.

Smith, T B, Holstein, D M, Ennis, R S, 2019. Disturbance in mesophotic coral ecosystems and linkages to conservation and management. In: Loya, Y, Puglise, K, Bridge, T (Eds.), Mesophotic Coral Ecosystems. In: Coral Reefs of the World. Springer, Cham, pp. 991-992. doi:10.1007/978-3-319-92735-0 47.

Smythe, T C, 2017. Marine spatial planning as a tool for regional ocean governance? An analysis of the New England ocean planning network. Ocean Coast. Manag. 135, 11-24. doi:10.1016/j.ocecoaman.2016.10.015.

Soares, M O, 2018. Climate change and regional human pressures as challenges for management in oceanic islands, South Atlantic. Mar. Pollut. Bull. 131, 347-355. doi:10.1016/j.marpolbul.2018.04.008.

Soares, M O, 2020. Marginal reef paradox: a possible refuge from environmental changes? Ocean Coast. Manag. 185 (1), 105063. doi:10.1016/j.ocecoaman.2019.105063.

Soares, M O, Tavares, T, Carneiro, P B M, 2019. Mesophotic ecosystems: distribution, human impacts, and conservation in the South Atlantic. Divers. Distrib. 25, 255-268 doi:10.1111/ddi.1284

Soares, M O, Teixeira, C E P, Bezerra, L E A, Rossi, S, Tavares, T C L, Cavalcante, R M, 2020. Brazil oil spill response: Time for coordination. Science 367 (6474), 155 doi:10.1126/science.aaz9993.

Spalding, M D, Fox, H E, Allen, G R, Davidson, N, Ferdaña, Z A, Finlayson, M, Halpern, B S, Jorge, M A, Lombana, A, Lourie, S A, Martin, K D, McManus, E, Molnar, J, Recchia, C A, Robertson, J, 2007. Marine ecoregions of the world: a bioregionalization of coasta and shelf areas. BioScience 57 (7), 573-583. doi:10.1641/B570707.

Tornabene, L, van Tassell, J L, Robertson, D R, Baldwin, C C, 2016. Repeated invasions into the twilight zone: evolutionary origins of a novel assemblage of fishes from deep Caribbean reefs. Mol. Ecol. 25, 3662-3682. doi:10.1111/mec.13704.

Trembanis, A C, Forrest, A L, Keller, B M, Patterson, M R, 2017. Mesophotic cora ecosystems: a geoacustically derived proxy for habitat and relative diversity for the leeward shelf of Bonaire, Dutch Caribbean. Front. Mar. Sci. 4, 51. doi:10.3389/ fmars.2017.00051.

Turner, J A, Babcock, R C, Kendrick, G A, 2017. Deep thinking: a systematic review of mesophotic coral ecosystems. ICES J. Mar. Sci. 74 (9), 2309-2320. doi:10.1093/ icesjms/fsx085.

Turner, J A, Andradi-Brown, D A, Gori, A, Bongaerts, P, Burdett, H L, Ferrier-Pagès, C, Voolstra, C R, Weinstein, D K, Bridge, T, Costantini, F, Gress, E, Laverick, J, Loya, Y, Goodbody-Gringley, G, Rossi, S, Taylor, M L, Viladrich, N, Voss, J, Williams, J, Woodall, L C, Eyal, G, 2019. Key questions for research and conservation of mesophotic coral ecosystems and temperate mesophotic ecosystems. In: Loya, Y, Puglise, K, Bridge, T (Eds.), Mesophotic Coral Ecosystems. In: Coral Reefs of the World. Springer, Cham, pp. 989-1003. doi:10.1007/978-3-319-92735-0_52.

Venegas, R M, Oliver, T, Liu, G, Heron, S F, Clark, J, Pomeroy, N, Young, C, Eakin, C M, Brainard, R E, 2019. The rarity of depth refugia from coral bleaching heat stress in the western and central Pacific Islands. Sci. Rep. 9, 19710. doi:10.1038/ s41598-019-56232-1.

Zhang, L, Zhang, S, Wang, Y, Yu, K, Li, R, 2019. The spatial distribution of microplastic in the sands of a coral reef island in the South China Sea: comparisons of the fringing reef and atoll. Sci. Total Environ. 688, 780-786. doi:10.1016/j.scitotenv.2019.06.178. 